Communication

\title{
Fumigation of Insect-Infested Wooden Logs by EDN Using Two Scenarios of Plastic Tent-Tarpaulin Sealing: Wooden Logs Stacks Placed on Bottom Plastic Sheets or Directly on Underlying Soil
}

\author{
Jonas Hnatek 1,2,*, Vaclav Stejskal ${ }^{1,3, * \mathbb{D}}$, Tomas Vendl ${ }^{3}$, Radek Aulicky ${ }^{3}$, Jarmila Malkova ${ }^{2}$ and \\ Miloslav Zouhar ${ }^{1}$ (D)
}

Citation: Hnatek, J.; Stejskal, V.; Vendl, T.; Aulicky, R.; Malkova, J.; Zouhar, M. Fumigation of Insect-Infested Wooden Logs by EDN Using Two Scenarios of Plastic Tent-Tarpaulin Sealing: Wooden Logs Stacks Placed on Bottom Plastic Sheets or Directly on Underlying Soil Sustainability 2021, 13, 13377. https:/ / doi.org/10.3390/su132313377

Academic Editor:

Bernhard Huchzermeyer

Received: 8 November 2021

Accepted: 27 November 2021

Published: 3 December 2021

Publisher's Note: MDPI stays neutral with regard to jurisdictional claims in published maps and institutional affiliations.

Copyright: (c) 2021 by the authors. Licensee MDPI, Basel, Switzerland. This article is an open access article distributed under the terms and conditions of the Creative Commons Attribution (CC BY) license (https:// creativecommons.org/licenses/by/ $4.0 /)$.
1 Department of Plant Protection, Faculty of Agrobiology Food and Natural Resources, Czech University of Life Sciences Prague, Kamýcká 129, 16500 Prague 6, Suchdol, Czech Republic; zouhar@af.czu.cz

2 Lučební závody Draslovka a.s., Havlíčkova 605, Kolín IV, 28002 Kolín, Czech Republic; jarmila.malkova@draslovka.cz

3 Division of Plant Health, Crop Research Institute Prague, Drnovská 507, 16106 Prague 6, Ruzyně, Czech Republic; vendl@vurv.cz (T.V.); aulicky@vurv.cz (R.A.)

* Correspondence: jonas.hnatek@draslovka.cz (J.H.); stejskal@vurv.cz (V.S.)

Abstract: Recently, the largest bark beetle calamity (Ips typographus) of the last 100 years has erupted in Central Europe, including the Czech Republic. This calamity may threaten the sustainability of growing large areas of monoculture Norway spruce (Picea abies) in this area. Limited economically feasible physical and chemical pest control options are available to prevent the bark beetle spread. However, from these options, only mechanical bark removal or gas-insecticide fumigation result in instant deactivation of all pest stages throughout the entire stack of stored logs. Due to the ban on the use of methyl bromide (MeBr) for the fumigation of log piles under tarpaulin, the adaptation of the phyto-quarantine method EDN to the destruction of I. typographus bark beetles in harvested wood directly in forests was newly proposed in the Czech Republic. The methodical experience with fumigation of the harvested logs, however, was only available for wood fumigation in chambers or in tent-tarps fumigation placed on paved (concrete/asphalt) surfaces mainly in ship harbors. Prior to the introduction of the new EDN fumigation method of bark beetle infested wood stored directly in the forests, it was initially unclear whether it was necessary to use or neglect bottom sheets to optimize exposure and maximize Ct products for the permitted fixed initial dose $\left(50 \mathrm{~g} \cdot \mathrm{m}^{-3}\right)$. Therefore, the initial validation pilot trials were aimed at the estimation and comparison of EDN temporal dynamics and $\mathrm{Ct}$ products under real forest conditions and two fumigation scenarios: Wooden log pile placed on bottom plastic sheets or directly on soil without the bottom sheets. Field trials were performed under both identical as well as different environmental conditions. In addition, they revealed that the concentration decrease was significantly faster and $\mathrm{Ct}$ products were significantly lower in the case of trials without the bottom sheets. The experiments indicated high EDN sorption by the uncovered soil under the tent. Quantitatively, the average Ct product was 4.8 (identical conditions) and 3.7 (different conditions) times lower in EDN trials without the bottom sheets when compared to the use of bottom sheets. The initial field-forest fumigation validation trials indicated a necessity to carry out EDN fumigation under tent-tarps also using bottom sheets, although this fumigation procedure increases the labor-demands to some extent. Based on the presented results and additional data, the Czech authority issued for the EDN plant protection product an authorization for the limited and controlled use of wooden logs. Therefore, this work became the basis of the historically and first officially authorized use of any fumigant for pest control under commercial forest conditions.

Keywords: sustainable forest protection; Norway spruce; Picea abies; eight-toothed bark beetle; outbreak mitigation; quarantine; ethanedinitrile; soil sorption 


\section{Introduction}

Since 2015, forest owners in the Czech Republic and also in most of Central Europe have been facing the largest bark beetle calamity to date. Spruce forests (Norway spruce, Picea abies (L.) Karsten) are infested with the European eight-toothed spruce bark beetle, Ips typographus (L.). Ips typographus is classified as a serious pest by the EFSA scientific opinion [1]. In addition, it is considered a quarantine pest in protected zones of the EU. To obtain an insight into the seriousness of the calamity, it is worth mentioning that in 2019, 20.7 million $\mathrm{m}^{3}$ of harvested spruce bark beetle infested wood was registered in the Czech Republic, which represents an increase compared to 2018 by more than $70 \%$, when approximately 12 million $\mathrm{m}^{3}$ was recorded (in 2017, it was 5.34 million $\mathrm{m}^{3}$ ) [2]. Quarantine measures are implemented to prevent entry in yet uncolonized areas [1]. A prerequisite for a successful control and geographical spread limitation of bark beetles is a fast and effective phyto-quarantine remediation, which, however, is challenged by ecological demands and economic and technical constraints. Limited economically feasible physical and chemical pest control options are available to prevent the bark beetle spread. Several available methods may include mechanical debarking, pheromone application, as well as heat and chemical treatment using the plant protection product, such as sprays, insecticidal nets, and fumigation. If conducted properly, mechanical debarking-using sophisticated machines-is highly effective in terms of pest control and can be used during the whole developmental cycle of the bark beetles. However, a major limiting factor of the mechanical treatment is time constraint during the calamity pest outbreak. Although several spray-insecticide products for the surface treatment of wood (bark) against the bark beetle are currently registered, the chemical spray deactivation is not instant and usually does not lead to $100 \%$ control [3]. The major problem of spraying and especially of the nets is the fact that they do not kill the bark beetle inside the wood. Therefore, the beetle can fly out during further handling (scraping the treated bark) and transfer, as well as attack other trees. Another disadvantage of spraying and netting is that it affects the non-target organism $[4,5]$. The heat treatment requires transport to specialized facilities. Van Haandel et al. [6] did not obtain the information on irradiation, which was implemented as an operational solution for large-volume wooden commodities in any country.

However, from the previously mentioned options, only bark mechanical removal, irradiation, modified atmospheres or gas-insecticide fumigation result in instant deactivation of all the bark beetle pest stages throughout the entire stack of stored logs. The gaseous form (fumigants/modified atmospheres) of insecticides enables in-depth wood and commodity penetration, as well as instant inactivation of all the pest stages, i.e., eggs, larvae, pupae, and adults $[7,8]$. The rapid action is important since bark beetles have a high rate of colonization dynamics [1]. Unlike other countries and territories (e.g., [9]), methyl bromide $(\mathrm{MeBr})$ is not registered in the EU and is not allowed for use even in critical quarantine exemptions since it is considered a serious ozone depletor. Fumigants registered in the EU $\left(\mathrm{HCN}, \mathrm{PH}_{3}, \mathrm{SO}_{2} \mathrm{~F}_{2}\right)$ are mainly used as biocides for the treatment of structural wood [10] or for specific cases, such as plant protection products for wood treatment in containers. Although multiple tests were performed and published on $\mathrm{HCH}$ as a phyto-quarantine [10] or crop seedlings fumigant (e.g., [11]), the registration for this purpose is not in the proximate stage. Therefore, as an alternative to the previously mentioned fumigants, EDN (active substance ethanedinitrile) was proposed for the fumigation of the bark beetle infested logs (stacked and treated under tarpaulin) to mitigate the spread of bark beetle calamity. Ethanedinitrile, also known as Cyanogen, Dicyan $\left(\mathrm{C}_{2} \mathrm{~N}_{2}\right)$ or Oxalonitrile, is a colorless gas with pungent odor. Its molecular weight is 52 and relative gas density is 1.82 [12].

The technical and economical prerequisites that made the plan a practical choice were the fact that the required quantities of EDN are produced and available in the Czech Republic. The newly intended use of EDN was enabled by the accumulated promising knowledge and international experience regarding the EDN efficacy on a vast array of pests and commodities in the last two decades [13-16]. EDN was suggested for multiple organism and pest control areas: Wood [17-20], soil [11], and stored commodities [21,22]. 
EDN has potentially good physical and environmental properties that are required for its use as a wood fumigant under tarpaulin on the open forest landscape. EDN does not damage the ozone layer [21] and all of the degradation products of EDN naturally occur in the environment [23]. Moreover, EDN degradation does not produce other harmful compounds [24]. EDN is heavier than air and other gases and therefore, is easy to apply and seal under tarps [19]. EDN quickly penetrates the whole profile of the wood (logs) [15], while the bark cover does not significantly influence its sorption [13]. Park et al. [25] proved that EDN has a great potential for the treatment of fresh pine wooden logs to manage nematodes and vector insects at low temperatures and also reported several successful field EDN-fumigation trials at low temperatures [26]. The recent work by Park et al. (2021) [20] reported on laboratory and commercial-scale Korean trials with EDN on significant wood destroying pests, namely bark beetles Tomicus piniperda (L.) and Cryphalus fulvus (Niijima), the fall webworm Hyphantria cunea (Drury), and termite Reticulitermes speratus (Kolbe), which naturally infest pine logs.

The designed technology of EDN fumigation targets the organisms under a tarp (i.e., there is no "drift" to the surrounding vegetation with negative effects on non-target organisms and beneficial insects). EDN fumigation can use common tarpaulin plastic materials [16]. These commonly used and broadly available materials are also usually required by practitioners as low-cost sealing technologies that are suitable for effective fumigation practices [27]. However, both the experimental and practical field experience with EDN fumigation of logs were only available for wood fumigation in chambers or in tent-tarps fumigation placed on enforced or paved (concrete/tarred) surfaces. Prior to the introduction of the new EDN fumigation method of bark beetle infested wood stored in the forests in the Czech Republic, it was not initially clear whether it was necessary to use or neglect the bottom sheets to optimize exposure and maximize $\mathrm{Ct}$ products for the permitted fixed initial dose of $50 \mathrm{~g} \cdot \mathrm{m}^{-3}$. The Ct product describes "in a single number" the fumigation concentration dynamics over time. It indicates that-for defined environmental conditions - the effective pesticide dosage can be described by a function of the fumigant concentration and the fumigation exposure time, which is the concentration (C)-time (t) product $(\mathrm{Ct}-\mathrm{P})[7,28]$. Therefore, the aim of the presented research was to compare the fumigation with and without the bottom sheets, where the wood logs were stacked directly on the porous forest soil surface. The EDN concentration was measured during the four field-forest trials (the stack of logs ranged from 225 to $463 \mathrm{~m}^{3}$ ) and Ct products were calculated. Moreover, additional data such as log size, temperature, relative humidity, wind speed, and amount of precipitation were measured. The ultimate aim of EDN fumigation is to contribute to the elimination of damage and its spread to larger geographical dimensions and thus, contribute to the sustainability of the renewable forest resources.

\section{Materials and Methods}

\subsection{Experiment 1: Initial Field EDN Fumigation Efficacy Validation under Different Conditions}

Table 1 summarizes general (i.e., coordinates, date, initial dose) as well as specific (i.e., physical and environmental conditions) information regarding four fumigation field trials. The treatments took place directly in the forest (Figure $1 \mathrm{~A}-\mathrm{C}$ ) at the place where the wood is harvested. The locality of Trial No. 1 was Licibořice (Chrudim Dist., Czech Republic), Trial No. 2 took place in locality Březina (Svitavy Dist., Czech Republic), and Trials No. 3 and 4 in locality Věšín (Př́bram Dist., Czech Republic). In the trials conducted within Experiment 1, four wood piles/stacks were fumigated. The wood was stacked on a bottom plastic sheet (Figure 1A) and the entire upper wood pile surface was covered with a plastic tarp, which was connected to the bottom sheet by spring clamps. 
Table 1. General and specific information (initial dose, physical and environmental conditions) on Experiment 1: Initial field validation under different conditions, and Experiment 2: Field validation under identical conditions.

\begin{tabular}{|c|c|c|c|c|c|c|}
\hline \multirow[b]{2}{*}{$\begin{array}{c}\text { Experiment and } \\
\text { Trial }\end{array}$} & \multicolumn{4}{|c|}{ Experiment 1} & \multicolumn{2}{|c|}{ Experiment 2} \\
\hline & $\begin{array}{l}\text { Trial No. } 1 . \\
\text { Wood Pile } \\
\text { with Bottom } \\
\text { Sheet }\end{array}$ & $\begin{array}{c}\text { Trial No. } 2 . \\
\text { Wood Pile with } \\
\text { Bottom Sheet }\end{array}$ & $\begin{array}{l}\text { Trial No. } 3 . \\
\text { Wood Pile } \\
\text { without } \\
\text { Bottom Sheet }\end{array}$ & $\begin{array}{l}\text { Trial No. } 4 . \\
\text { Wood Pile } \\
\text { without } \\
\text { Bottom Sheet }\end{array}$ & $\begin{array}{l}\text { Trial Nos. 1-5. } \\
\text { Wood Piles } \\
\text { with Bottom } \\
\text { Sheet }\end{array}$ & $\begin{array}{c}\text { Trial Nos. 6-10. } \\
\text { Wood Piles } \\
\text { without } \\
\text { Bottom Sheet }\end{array}$ \\
\hline Date & 1 April 2017 & 8 April 2017 & \multicolumn{2}{|c|}{19 September 2017} & \multicolumn{2}{|c|}{15 October 2021} \\
\hline Coordinates & $\begin{array}{l}49.8691562 \mathrm{~N} \\
15.8100427 \mathrm{E}\end{array}$ & $\begin{array}{l}49.63475833 \mathrm{~N} \\
16.59741666 \mathrm{E}\end{array}$ & \multicolumn{2}{|c|}{$49.6311864 \mathrm{~N}, 13.7992239 \mathrm{E}$} & \multicolumn{2}{|c|}{$50.8239758 \mathrm{~N}, 14.2903497 \mathrm{E}$} \\
\hline $\begin{array}{l}\text { Size of fumigated } \\
\text { stack (i.e., volume } \\
\text { of wooden logs } \\
\text { under tarp-tent) }\end{array}$ & $225 \mathrm{~m}^{3}$ & $453 \mathrm{~m}^{3}$ & $248 \mathrm{~m}^{3}$ & $364 \mathrm{~m}^{3}$ & $12 \mathrm{~m}^{3}$ & $12 \mathrm{~m}^{3}$ \\
\hline EDN-dose used * & $11.25 \mathrm{~kg}$ & $22.6 \mathrm{~kg}$ & $12.4 \mathrm{~kg}$ & $18.3 \mathrm{~kg}$ & $0.6 \mathrm{~kg}$ & $0.6 \mathrm{~kg}$ \\
\hline $\begin{array}{c}\text { EDN } \\
\text { concentration } \\
\text { monitoring } \\
\text { points (MP) }\end{array}$ & \multicolumn{4}{|c|}{$\begin{array}{l}\text { 1. } 0.5 \mathrm{~m} \text { high, left } \\
\text { 2. } 1 \mathrm{~m} \text { high, middle } \\
\text { 3. } 1.5 \mathrm{~m} \text { high, right }\end{array}$} & \multicolumn{2}{|c|}{$1 \mathrm{~m}$ high, middle } \\
\hline $\begin{array}{l}\text { Average air } \\
\text { temperature } \\
\text { under tarp }\end{array}$ & $2.2^{\circ} \mathrm{C}$ & $10.4^{\circ} \mathrm{C}$ & $8.6^{\circ} \mathrm{C}$ & $8.6^{\circ} \mathrm{C}$ & $13.9^{\circ} \mathrm{C}$ & $13.7^{\circ} \mathrm{C}$ \\
\hline $\begin{array}{l}\text { Average } \mathrm{RH} \text { of air } \\
\text { under tarp }\end{array}$ & $77.1 \%$ & $84.9 \%$ & $88.4 \%$ & $88.4 \%$ & $84.0 \% \mathrm{RH}$ & $90.8 \% \mathrm{RH}$ \\
\hline Wood moisture & \multicolumn{6}{|c|}{ Fresh wood, moisture over $50 \%$} \\
\hline $\begin{array}{l}\text { Average wind } \\
\text { speed }\end{array}$ & $2 \mathrm{~m} / \mathrm{s}$ & $15 \mathrm{~m} / \mathrm{s}$ & $3 \mathrm{~m} / \mathrm{s}$ & $3 \mathrm{~m} / \mathrm{s}$ & \multicolumn{2}{|c|}{$2 \mathrm{~m} / \mathrm{s}$} \\
\hline
\end{tabular}

* The amount of used product, calculated depending on the volume of the pile.

The trials without the bottom sheet were performed in accordance with the same methodology, except that the bottom sheet was not used (Figure 1B). The wood was stacked directly on the forest soil and the whole wood pile was covered with tarp, which was weighed down and sealed with sand bags. Two trials (log piles/stacks) were fumigated with the bottom sheets and two wood piles were fumigated without the bottom sheets. Both the upper tent-tarps and the bottom sheets used for all fumigations were recommended by the EDN product manufacturer (PE black silage non-welded tarp/sheet with the minimum thickness of $0.12 \mathrm{~mm}$ ). The loading factor ranged between $60 \%$ and $64 \%$.

Sampling and application sites (hoses) were placed on the selected positions (one application site per about $200 \mathrm{~m}^{3}$ of wood). The application hoses were connected to the application equipment and EDN cylinder containing $50 \mathrm{~kg}$ of the product. EDN was pushed out of the cylinder by inert gas (nitrogen) into the fumigated space at a dose of $50 \mathrm{~g} / \mathrm{m}^{3}$ of the covered space (Figure 1D). The dose was determined according to the cylinder weight loss monitored on the scales on which the cylinder was placed. Sampling and application hoses were inserted $1 \mathrm{~m}$ deep into the wooden pile. Sampling points were selected to represent all of the heights in the wooden pile (Figure 2A) and were located on the same side of the pile as the application points, but at the greatest distance as possible. Ventilation began after $10 \mathrm{~h}$ of treatment by gradually uncovering the fumigated space. 


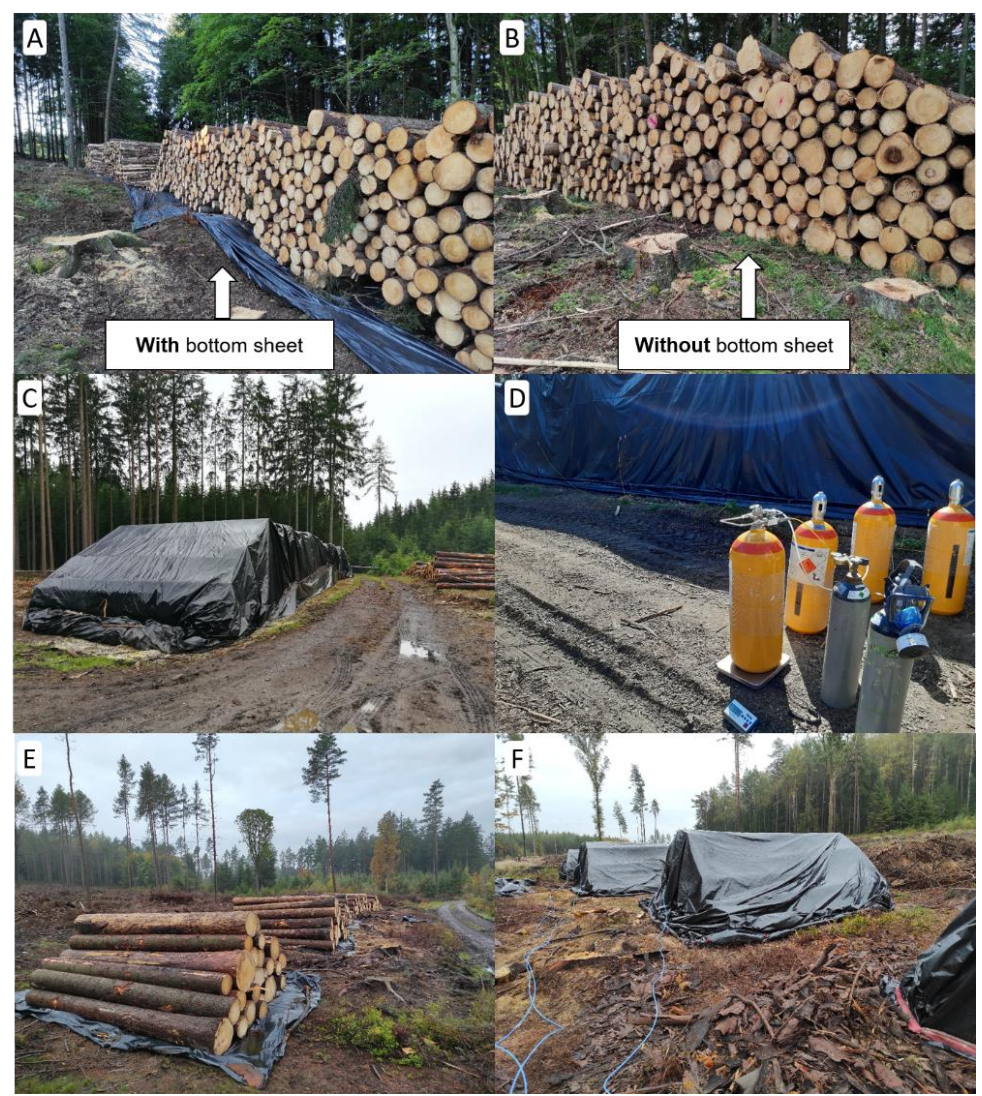

Figure 1. Visualization of EDN $\log$ stack fumigation under different $(\mathbf{A}-\mathbf{C})$ and identical (E,F) conditions. (A) Detail of the lower part of the log stack with bottom sheet; (B) detail of the lower part of the log stack without bottom sheet; (C) fumigated log stacks covered by an upper tarpaulin tent; (D) EDN application from the cylinder; (E) uncovered log stacks with bottom sheet; (F) fumigated covered log stacks with bottom sheet.
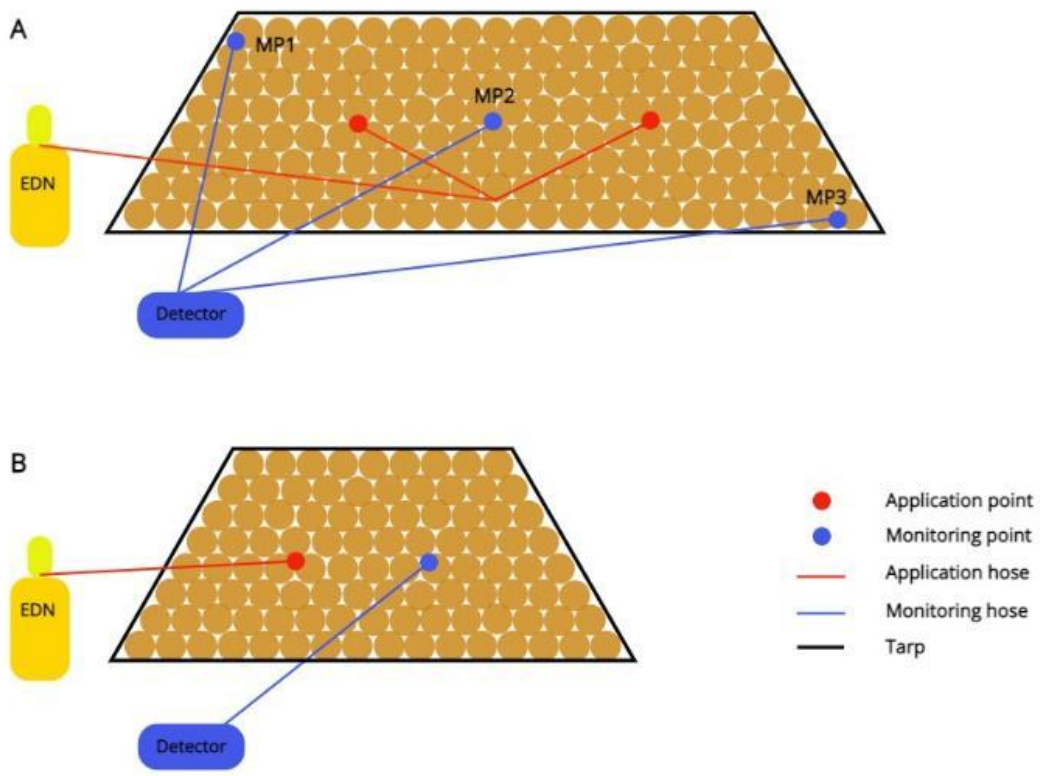

Figure 2. Schematic configuration of log stacks, sampling points (blue dots), and EDN gas application sites/points (red dots) during experimental fumigation under different conditions (A) and under identical conditions (B). 
The EDN concentration was monitored continuously using the FTIR detector Gasmet DX 4040 (Gasmet Technologies Oy, Finland). During the treatment, the temperature and relative humidity were monitored by means of digital data loggers TinyTag plus 2 (Gemini Data Loggers Ltd., United Kingdom). Wood moisture was measured by the moisture meter TESTO 616 (Testo s.r.o., Czech Republic). Other variables measured during the treatment were precipitation, wind direction, and speed recorded by the IROX PRO-X weather station (OS Technology AG/SA, Switzerland).

\subsection{Experiment 2: Field EDN Fumigation Efficacy Validation under Identical Conditions}

The trials without the bottom sheet were performed in accordance with the same methodology as in Experiment 1: Initial field validation under different conditions.

In the trials conducted within the framework of Experiment 2, 10 wood piles/stacks were fumigated. Five trials (wood piles/stacks) were fumigated with the bottom sheets and five wood piles were fumigated without the bottom sheets (Figure 1E,F) in the locality Bynovec (Děčín Dist., Czech Republic). Due to the relatively small size of the wood piles, one application and one sampling point were used in each pile (Figure 2B). The $10 \log$ piles were all fumigated at one place and on the same date (15 October). General (coordinates, date, initial dose) and specific information (physical and environmental conditions) regarding the 10 fumigation field trials are summarized in Table 1.

Differences in the EDN concentration and the Ct products between the trials were tested with a one-way ANOVA. The means of log transformed values were separated by Tukey's post hoc test, with $p<0.05$ considered to be statistically significant. The Ct product was estimated based on Bond [29].

\section{Results}

\subsection{Experiment 1: Initial Field EDN Fumigation Efficacy Validation under Different Conditions}

Figure 3 shows the dynamics of EDN concentration at 3 locations (MP1-0.5 $\mathrm{m}$ high on the left, MP2-1 m high in the middle, MP3-1.5 m high on the right-see Figure 2) inside the fumigated log stacks covered by an upper tarpaulin tent. Specifically, Figure 3A,B shows EDN dynamics with the bottom plastic sheet, while Figure 3C,D without the bottom plastic sheets. The maximum and final concentrations are summarized in Table 2 , and Ct products are summarized and statistically compared in Table 3.

Table 2. EDN concentration dynamics during four fumigation trials measured at various locations inside log stacks (MP1, MP2, and MP3). For each trial, the initially applied dose was $50 \mathrm{~g} \cdot \mathrm{m}^{-3}$ and the fumigation exposure time was $10 \mathrm{~h}$.

\begin{tabular}{|c|c|c|c|c|c|}
\hline $\begin{array}{l}\text { Fumigation } \\
\text { Trialed Bottom } \\
\text { Sheet (b-s) }\end{array}$ & $\begin{array}{l}\text { Sampling } \\
\text { Point }\end{array}$ & $\begin{array}{c}\text { Maximum MP1-MP3 } \\
\text { Concentrations } \\
\left(\mathrm{g} \cdot \mathrm{m}^{-3}\right)\end{array}$ & $\begin{array}{c}\text { Mean } \pm \text { SE Maximum } \\
\text { Concentrations } \\
\left(\mathrm{g} \cdot \mathrm{m}^{-3}\right)\end{array}$ & $\begin{array}{c}\text { End MP1-MP3 } \\
\text { Concentrations } \\
\quad\left(\mathrm{g} \cdot \mathrm{m}^{-3}\right)\end{array}$ & $\begin{array}{c}\text { Mean } \pm \text { SE End } \\
\text { Concentrations } \\
\quad\left(\mathrm{g} \cdot \mathrm{m}^{-3}\right)\end{array}$ \\
\hline \multirow{3}{*}{ Trial 1 with b-s } & MP 1 & 40.0 & \multirow{3}{*}{$42.1 \pm 1.2$} & 8.5 & \multirow{3}{*}{$8.0 \pm 1.26$} \\
\hline & MP 2 & 42.4 & & 9.5 & \\
\hline & MP 3 & 44.1 & & 6.0 & \\
\hline \multirow{3}{*}{ Trial 2 with b-s } & MP 1 & 47.3 & \multirow{3}{*}{$52.4 \pm 2.6$} & 5.2 & \multirow{3}{*}{$5.1 \pm 0.07$} \\
\hline & MP 2 & 54.0 & & 5.0 & \\
\hline & MP 3 & 56.0 & & 5.0 & \\
\hline \multirow{3}{*}{ Trial 3 without b-s } & MP 1 & 30.0 & \multirow{3}{*}{$30.9 \pm 5.8$} & 0.2 & \multirow{3}{*}{$0.4 \pm 0.22$} \\
\hline & MP 2 & 41.4 & & 0.1 & \\
\hline & MP 3 & 21.2 & & 0.8 & \\
\hline \multirow{3}{*}{ Trial 4 without b-s } & MP 1 & 13.5 & \multirow{3}{*}{$16.0 \pm 2.2$} & 1.0 & \multirow{3}{*}{$1.1 \pm 0.23$} \\
\hline & MP 2 & 14.1 & & 1.5 & \\
\hline & MP 3 & 20.4 & & 1.8 & \\
\hline
\end{tabular}


A

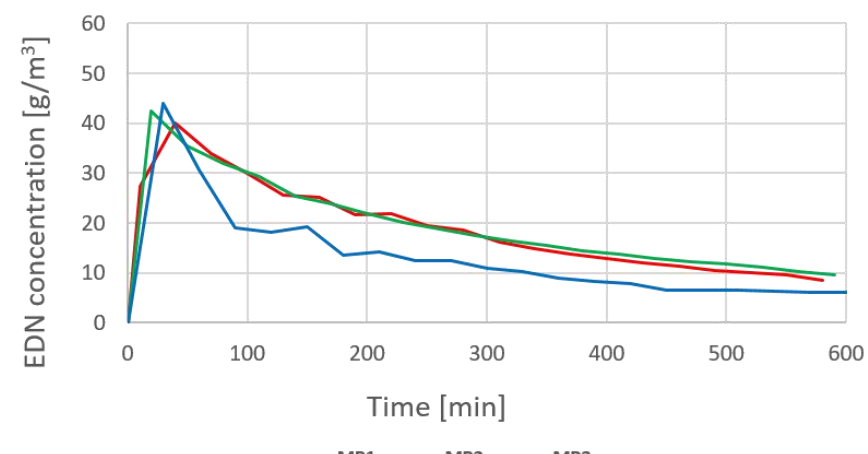

C

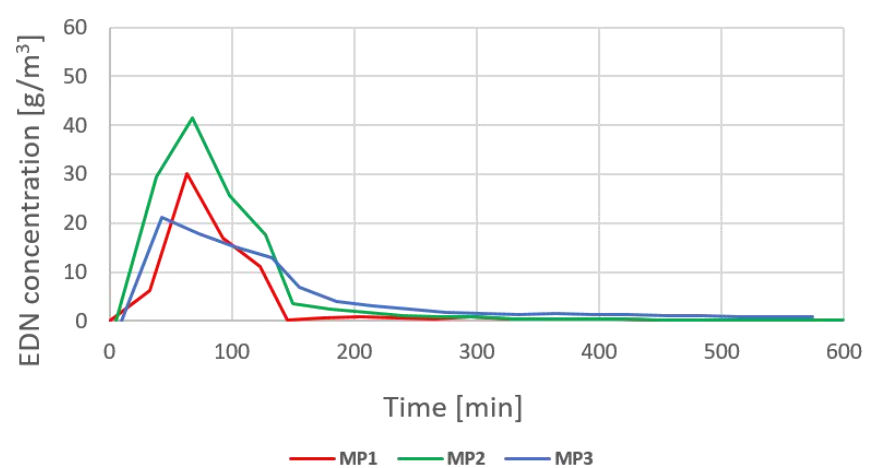

B

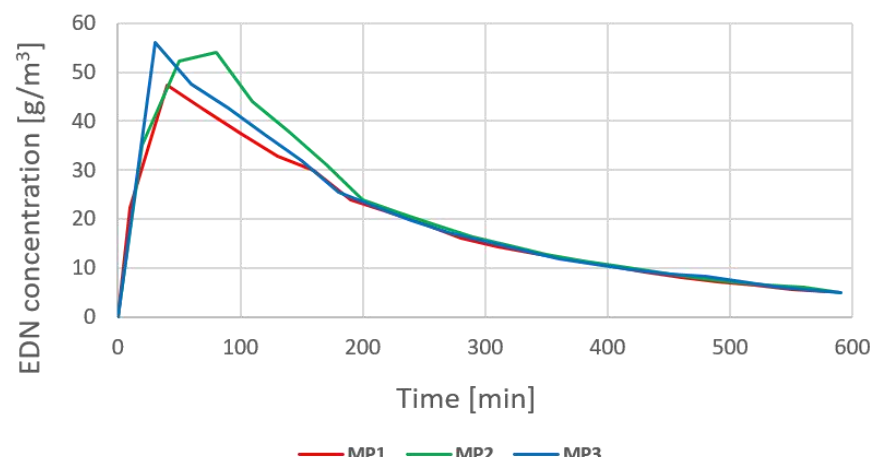

D

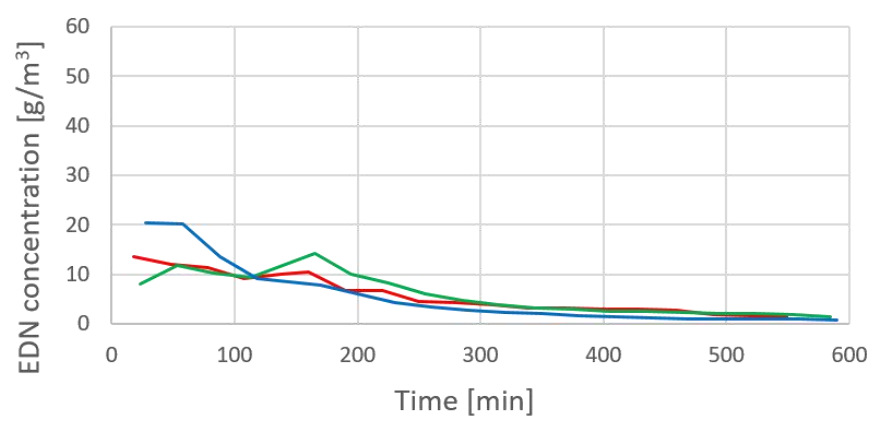

Figure 3. EDN concentration during fumigation with and without the bottom sheet. (A) 1st fumigation with bottom sheet; (B) 2nd fumigation with bottom sheet; (C) 1st fumigation without bottom sheet; (D) 2nd fumigation without bottom sheet. In all of the cases, the initially applied EDN dose ("target concentration") was $50 \mathrm{~g} \cdot \mathrm{m}^{-3}$.

Table 3. Ct products obtained during fumigation in four trials and at three sampling points (MP1, MP2, and MP3: MP1-0.5 $\mathrm{m}$ high on the left, MP2-1 m high in the middle, MP3-1.5 m high on the right, see Figure 2) inside each fumigated log pile. For each trial, the initially applied dose was $50 \mathrm{~g} \cdot \mathrm{m}^{-3}$ and the fumigation exposure time was $10 \mathrm{~h}$.

\begin{tabular}{|c|c|c|c|c|}
\hline Fumigation & Bottom Sheet & Sampling Point & Ct Product $\left(\mathrm{g} \cdot \mathrm{h} \cdot \mathrm{m}^{-3}\right)$ & Mean \pm SE $\left(\mathrm{g} \cdot \mathrm{h} \cdot \mathrm{m}^{-3}\right)$ \\
\hline \multirow{3}{*}{ Trial 1} & \multirow{3}{*}{ Yes } & MP 1 & 184.5 & \multirow{3}{*}{$169.2 \pm 18.9$} \\
\hline & & MP 2 & 191.5 & \\
\hline & & MP 3 & 131.6 & \\
\hline \multirow{3}{*}{ Trial 2} & \multirow{3}{*}{ Yes } & MP 1 & 185.3 & \multirow{3}{*}{$196.9 \pm 6.4$} \\
\hline & & MP 2 & 207.3 & \\
\hline & & MP 3 & 198.1 & \\
\hline \multirow{3}{*}{ Trial 3} & \multirow{3}{*}{ No } & MP 1 & 30.5 & \multirow{3}{*}{$46.1 \pm 8.8$} \\
\hline & & MP 2 & 60.8 & \\
\hline & & MP 3 & 47.0 & \\
\hline \multirow{3}{*}{ Trial 4} & \multirow{3}{*}{ No } & MP 1 & 53.5 & \multirow{3}{*}{$54.2 \pm 1.2$} \\
\hline & & MP 2 & 56.5 & \\
\hline & & MP 3 & 52.5 & \\
\hline
\end{tabular}

The average maximum concentration was $42.1 \mathrm{~g}$ EDN $/ \mathrm{m}^{3}$ in the 1 st trial with the bottom plastic sheet, while it was $52.4 \mathrm{~g} \mathrm{EDN} / \mathrm{m}^{3}$ in the 2 nd trial. Without the bottom sheet, the average maximum concentration was $30.9 \mathrm{~g} \mathrm{EDN} / \mathrm{m}^{3}$ in the $3 \mathrm{rd}$ trial and $16 \mathrm{~g} \mathrm{EDN} / \mathrm{m}^{3}$ in the 4th trial. The final concentration before ventilation (at the end of the fumigations) with the bottom sheet was 8 and $5 \mathrm{~g} \mathrm{EDN} / \mathrm{m}^{3}$, respectively. Without the bottom sheet, the concentration was 0.4 and $1.1 \mathrm{~g} \mathrm{EDN} / \mathrm{m}^{3}$. The concentration decrease was much faster in 
the case of fumigation without the bottom plastic sheet. The average $\mathrm{Ct}$ product reached was $3.7 \times$ lower (Table 3). The average $\mathrm{Ct}$ product reached during fumigation with the bottom sheet was $169.2 \mathrm{~g} \cdot \mathrm{h} \cdot \mathrm{m}^{-3}$ in the $1 \mathrm{st}$ trial and $196.9 \mathrm{~g} \cdot \mathrm{h} \cdot \mathrm{m}^{-3}$ in the 2nd trial. During fumigation without the bottom sheet, the average Ct product was $46.1 \mathrm{~g} \cdot \mathrm{h} \cdot \mathrm{m}^{-3}$ in the 3rd trial and $54.2 \mathrm{~g} \cdot \mathrm{h} \cdot \mathrm{m}^{-3}$ in the 4 th trial.

\subsection{Experiment 2: Field EDN Fumigation Efficacy Validation under Identical Conditions}

Presence or absence of bottom sheet had a considerable effect on the dynamics of EDN concentration (Figure 4). The main characteristics and differences between log stacks with and without bottom sheet are provided in Table 4 . Specifically, the mean maximum and end concentrations were significantly higher in log stocks with bottom sheet than without it. In fact, EDN concentration dropped to zero on average after $431 \mathrm{~min}$ in log stacks without bottom sheet, but it did not reach zero in log stacks with bottom sheet at all. Similarly, there were clear differences in times of EDN concentration below $5 \mathrm{~g} \cdot \mathrm{m}^{-3} \mathrm{~g}$ (Table 4). The data further showed that EDN concentration decrease during fumigation without bottom sheet was not only much faster, but also more variable (see standard errors of mean concentrations in Figure 4). The reached average $\mathrm{Ct}$ products were roughly $4.8 \times$ lower in $\log$ stacks without bottom sheet than with it $\left(28.9 \mathrm{vs} .139 .8 \mathrm{~g} \cdot \mathrm{h} \cdot \mathrm{m}^{-3}\right)$.

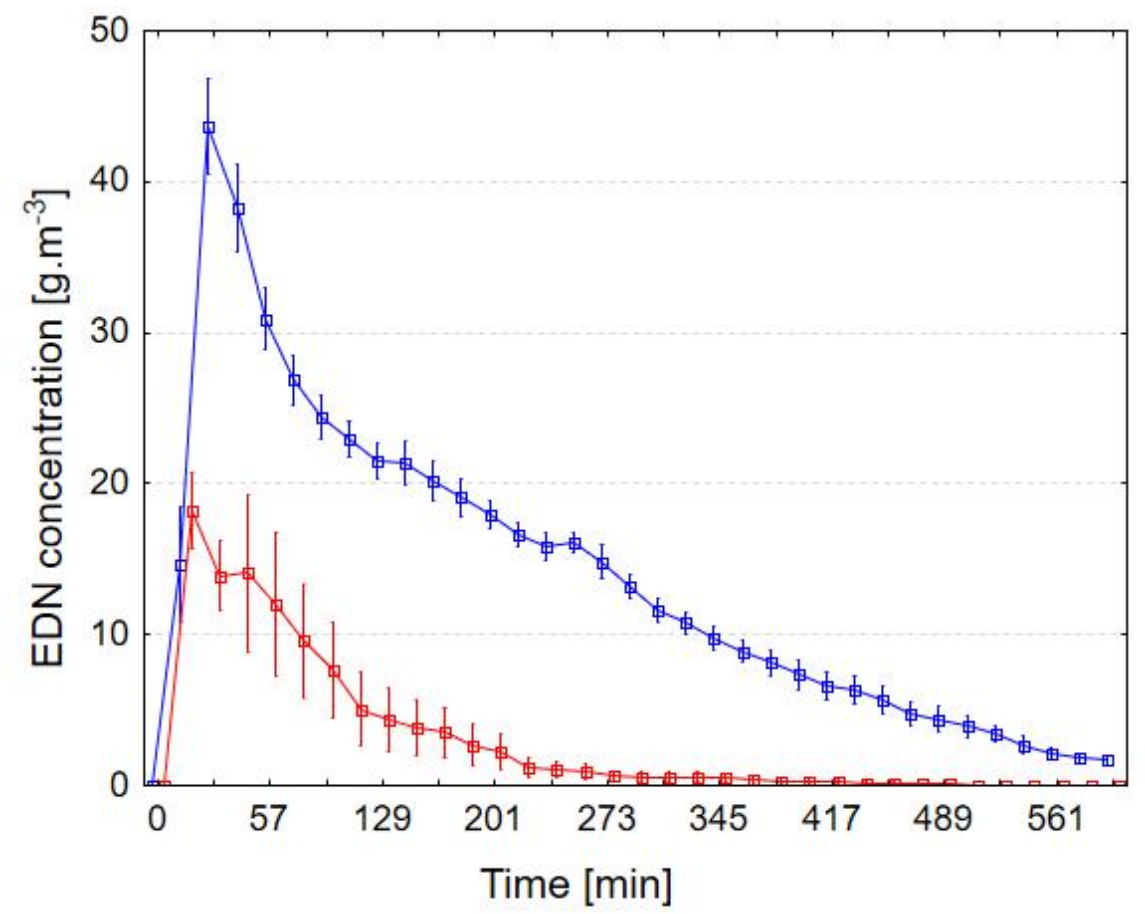

Figure 4. Mean ( \pm SE) EDN concentration during fumigation of log stacks with (blue curve) and without (red curve) the bottom sheet under identical conditions (Experiment 2). In both cases, the initially applied EDN dose ("target concentration") was $50 \mathrm{~g} \cdot \mathrm{m}^{-3}$.

Table 4. Concentration dynamics and Ct products obtained during fumigation of log stacks with and without the bottom sheet under identical conditions. Values are presented as means $\pm \mathrm{SE}$ ( $n=5$ for each treatment).

\begin{tabular}{|c|c|c|c|c|}
\hline Bottom Sheet & $\begin{array}{c}\text { Maximum } \\
\text { Concentration }\left(\mathrm{g} \cdot \mathrm{m}^{-3}\right)\end{array}$ & $\begin{array}{l}\text { End Concentration } \\
\qquad\left(\mathrm{g} \cdot \mathrm{m}^{-3}\right)\end{array}$ & $\begin{array}{l}\text { Time of Concentration } \\
\text { below } 5 \mathrm{~g} \cdot \mathrm{m}^{-3} \text { (min) }\end{array}$ & Ct Product $\left(\mathrm{g} \cdot \mathrm{h} \cdot \mathrm{m}^{-3}\right)$ \\
\hline Present & $44.1 \pm 2.92$ & $1.67 \pm 0.31$ & $471 \pm 19$ & $139.8 \pm 5.4$ \\
\hline Absent & $18.2 \pm 2.49$ & $0.002 \pm 0.002$ & $111 \pm 32$ & $28.9 \pm 10.3$ \\
\hline$t$-test & 6.8 & 5.4 & 9.6 & 9.6 \\
\hline$p$ & $<0.001$ & $<0.001$ & $<0.001$ & $<0.001$ \\
\hline
\end{tabular}




\section{Discussion}

The study revealed, for the first time, the profound effect of the two alternative sealing scenarios for wood fumigation under tent-tarps, in terms of the obtained $\mathrm{Ct}$ products for the fixed EDN dose $\left(50 \mathrm{~g} \cdot \mathrm{m}^{-3}\right)$ initially applied from the fumigation cylinders into a wood stack. The absence of the bottom plastic sheet had a clearly negative effect on the temporal EDN concentration dynamics during wood-log fumigation under the tarp. It is even visually apparent from Figure 3 and 4 that the obtained concentration decay curves for the alternative sealing scenarios differ profoundly. Quantitatively, the average Ct product was 4.8 (identical conditions) and 3.7 (different conditions) times lower during the EDN trials without the bottom than with the use of the bottom sheet.

A temporal decay of any type of insecticide gas concentration occurs in each fumigation under real-world conditions [30,31]. They are differentially affected by several factors that are manifested in each individual fumigation in practice, to a different extent. These factors may include the chemical type (molecule) and application formulation of the fumigant $[7,30])$, the amount of the initial fumigant dose, exposure time, weather conditions [32], wood/commodity loading factor, gas sorption properties, particular treated substrate (wood/commodity/soil), and quality of sealing of the enclosure in which the fumigated wood or commodity is located [13-15,30]. The level and quality of sealing of the fumigation enclosure (e.g., fumigation chamber, tarp tent, isolated freight container $[30,33,34])$ belong to the most important factors since they affect the actual level of fumigant losses due to its leakage into the surrounding environment [35]. In the case of tarpaulin usage, the quality and age of fumigation sheets may play a significant role on the retention of fumigants [36,37]. However, if one hypothetically assumes that the fumigated space is perfectly and impenetrably tight, the fumigant concentration still decreases in time. This phenomenon is caused by a gas sorption in the surface or inside of the matrix of the wood or plastic tarps [13-15]). Ren et al. [15], during their research, proved that $63 \%$ of EDN was absorbed by the timber block. In addition, Hall et al. [24] measured the EDN concentration during the test in a $28 \mathrm{~L}$ fumigation chamber at an initial dose of $50 \mathrm{~g}$ and $46 \%$ loading factor at 10 and $20^{\circ} \mathrm{C}$. After $10 \mathrm{~h}, 8.0 \pm 2.0 \mathrm{~g} \cdot \mathrm{m}^{-3}$ remained in the treated space at $10^{\circ} \mathrm{C}$.

The data and results obtained from our field trials regarding the EDN concentration dynamics are not directly comparable with any already published works of other authors. The only work that can be partly used for comparison is by Najar-Rodriguez et al. [16]. The authors conducted the EDN tarp fumigation of wooden logs (Pinus radia D. Don) placed on a firm tarred (asphalt) road surface as an insecticide phyto-quarantine experimental treatment. The general fumigant decay dynamics of the EDN concentration under tenttarps had a relatively analogous characteristic and pattern in our and Najar-Rodriguez et al.'s [16] experiments. However, there were some significant differences in absolute values of the measured fumigation parameters. For instance, the experiments performed by Najar-Rodriguez et al. [16] showed a great consistency in the relation between the initial dose rate and the values of final concentrations at the end of the treatment period across all of the nine confirmatory fumigation field trials. Less than $1 \%$ of the applied concentration remained at the end of each fumigation, regardless of the initial applied dose or target EDN concentration. In our experiments, the relation between the initial dose rate and the values of the final concentration was $16 \%$ and $10 \%$ in fumigations with the bottom sheet. This difference was most likely caused by a shorter exposure time. However, the results of Najar-Rodriguez et al. [16] were more similar to our trials without the bottom sheet, in which these values ranged from $0.8 \%$ to $2.2 \%$. There were also differences in the initially applied EDN dose (termed as "target concentration" in the work by Najar-Rodriguez et al. [16] and the obtained initial concentrations measured inside the fumigation stack under a tent-tarp. In the study by Najar-Rodriguez et al. [16], these values were higher. For instance, they reached $124 \%$ for the applied dose of $120 \mathrm{~g} \cdot \mathrm{m}^{-3}$. In our experiments with the bottom sheet, the average achieved concentration was $94.4 \%$ of the initially applied dose, and $46.9 \%$ in the case of fumigation without the bottom sheet. The latter indicates 
that sorption in the uncovered soil was not only high overall, but the rate of sorption was high from the start of the fumigation.

In the fumigation practice, rather than complex decay curves, a simplified descriptive parameter (so-called cumulative Ct product) is used to validate the set goal $[7,28]$. The $\mathrm{Ct}$ products achieved in our trials with EDN during the fumigation of log stacks ranged from 46 to $169 \mathrm{~g} \cdot \mathrm{h} \cdot \mathrm{m}^{-3}$ for an identical initial dose $\left(50 \mathrm{~g} \cdot \mathrm{m}^{-3}\right)$. However, the values of $\mathrm{Ct}$ products differed significantly $(4.2$ or $3.7 \times$ ) only between the trials with different types of sealing. This implies that fumigation without the bottom sheet leads to a significant loss of the applied fumigant, which is not only economically acceptable, but may lead to a low bio-efficacy $[16,37]$. The previously mentioned field experiments conducted by Najar-Rodriguez et al. [16] achieved a series of different Ct products ranging from 515 to $818 \mathrm{~g} \cdot \mathrm{h} \cdot \mathrm{m}^{-3}$. Their Ct products were approximately $2.6-17.7 \times$ higher and more variable than those observed in our trials. The difference is not surprising. It likely results not only from the different types of treated wood logs (i.e., pine vs. spruce wood logs) and bottom surfaces on which they were placed (asphalt road vs. sheet covered/uncovered forest soil surface), but especially from the different initial EDN doses (our initial dose was $50 \mathrm{~g} \cdot \mathrm{m}^{-3}$, while their doses were 80,100, and $120 \mathrm{~g} \cdot \mathrm{m}^{-3}$ ) and exposure times (our exposure was $10 \mathrm{~h}$, while their exposure times included 16,20 , and $24 \mathrm{~h}$ ). The range of variability of Ct products obtained by Najar-Rodriguez et al. [16] was higher than in our experiments with the identical type of sealing. Of note, the lowest achieved product $\left(515 \mathrm{~g} \cdot \mathrm{h} \cdot \mathrm{m}^{-3}\right)$ was for the highest initial dose tested $\left(120 \mathrm{~g} \cdot \mathrm{h} \cdot \mathrm{m}^{-3}\right)$ and the shortest exposure time $(16 \mathrm{~h})$, while the highest $\mathrm{Ct}$ product was achieved for the mean values of the doses and times used $\left(100 \mathrm{~g} \cdot \mathrm{m}^{-3}\right.$ and $\left.20 \mathrm{~h}\right)$. This indicates that environmental factors for individual fumigation trials may also be important as demonstrated previously in other fumigation types [32]. In particular, temperature [38] and wind speed can play an important role [39,40]. Therefore, additional large-scale experiments are needed to explore the influence of other environmental weather factors on the EDN concertation dynamics and the resulting $\mathrm{Ct}$ products.

\section{Conclusions}

This work helped in the selection between two options of sealing wooden logs fumigated by EDN under tarps, in order to maximize Ct products for the fixed initial dose of $50 \mathrm{~g} \cdot \mathrm{m}^{-3}$. The key importance of the bottom sheet was determined during the trials. In the presented field fumigation experiments (i.e., conducted directly in forest conditions), the average $\mathrm{Ct}$ product was 4.8 times lower during the EDN trials without the bottom sheet than with the use of the bottom sheet. The international manual for EDN application (proposed by the EDN producer) states that the harvested wood shall be stored/piled at a prepared selected site. Depending on the physical/ chemical properties (i.e., sorption capacity) of the bottom surface, it is necessary to decide on the use of a bottom sheet. In case the fumigation takes place on a solid, flat, and at the same time EDN-impermeable surface (e.g., concrete), it is not necessary to use the bottom sheet. However, in all the other cases, it is imperative. In the outcome of our experimental work, we consider it important that based on the presented initial technical results and additional bio-efficacy data [41,42], the Czech authority issued for the EDN plant protection product an authorization for the limited (120 days) and controlled use of wooden logs in 2018. Since 2018, this exceptional authorization has been issued annually (last issued in 2021) and permits the use of EDN for the fumigation of logs infested with the bark beetle, in order to prevent the pest from spreading to new geographical areas. Therefore, this work became the basis of the historically and first officially authorized use of any fumigant under commercial forest conditions.

Author Contributions: Methodology, EDN treatment and measurements, writing-original draft preparation, J.H.; conceptualization, writing - review and editing, V.S.; data analysis and editing, T.V.; methodology, R.A. and M.Z.; visualization and editing, J.M. All authors have read and agreed to the published version of the manuscript. 
Funding: This research was partially supported by MŠMT TAČR TH02030329 and MZe ČR Výzkumný záměr RO. 014 projects.

Institutional Review Board Statement: Not applicable.

Informed Consent Statement: Not applicable.

Data Availability Statement: Data is deposited at the databases of all of the organizations involved in presented research: i.e. Lučební závody Draslovka a.s., Czech University of Life Sciences Prague, and Crop Research Institute.

Acknowledgments: We thank Jan Vokněr, Tereza Kupcová, and Michal Mošner (Lučební závody Draslovka a.s. Kolín, Czech Republic) for their technical support during fumigation.

Conflicts of Interest: The authors declare no conflict of interest. The funders had no role in the design of the study; in the collection, analyses, or interpretation of data; in the writing of the manuscript, or in the decision to publish the results.

\section{References}

1. EFSA PLH Panel (EFSA Panel on Plant Health); Jeger, M.; Bragard, C.; Caffier, D.; Candresse, T.; Chatzivassiliou, E.; DehnenSchmutz, K.; Gilioli, G.; Jaques Miret, J.A.; MacLeod, A.; et al. Scientific opinion on the pest categorisation of Ips typographus. EFSA J. 2017, 15, 23. [CrossRef]

2. Report on the State of Forests and Forest Management in the Czech Republic in 2019; The Ministry of Agriculture of the Czech Republic: Prague, Czech Republic, 2020; ISBN 978-80-7434-571-5.

3. Zahradník, P. Vaztak 10 EC v ochraně proti kůrovcům. Lesn. Práce 1995, 74, 30-31. (In Czech)

4. Frank, S.D.; Sadof, C.S. Reducing insecticide volume and nontarget effects of ambrosia beetle management in nurseries. J. Econ. Entomol. 2011, 104, 1960-1968. [CrossRef]

5. Skrzecz, I.; Grodzki, W.; Kosibowicz, M.; Tumialis, D. The alpha-cypermethrin coated net for protecting Norway spruce wood against bark beetles (Curculionidae, Scolytinae). J. Plant Prot. Res. 2015, 55, 156-161. [CrossRef]

6. van Haandel, A.; Kerr, J.L.; Laban, J.; Massart, X.; Murray, T.J.; O'connor, B.C.; Pawson, S.M.; Romo, C.M.; Walker, S. Tolerance of Hylurgus ligniperda (F.) (Coleoptera: Scolytinae) and Arhopalus ferus (Mulsant) (Coleoptera: Cerambycidae) to ionising radiation: A comparison with existing generic radiation phytosanitary treatments. N. Z. J. For. Sci. 2017, 47, 18. [CrossRef]

7. Stejskal, V.; Vendl, T.; Aulicky, R.; Athanassiou, C. Synthetic and natural insecticides: Gas, liquid, gel and solid formulations for stored-product and food-industry pest control. Insects 2021, 12, 590. [CrossRef] [PubMed]

8. Zhao, Q.-Y.; Li, T.-X.; Song, Z.-J.; Sun, T.; Liu, B.; Han, X.; Li, Z.-H.; Zhan, G.-P. Combination of modified atmosphere and irradiation for the phytosanitary disinfestation of Trogoderma granarium Everts (Coleoptera: Dermestidae). Insects 2021, $12,442$. [CrossRef]

9. Najar-Rodriguez, A.J.; Hall, M.; Adlam, A.; Afsar, S.; Esfandi, K.; Wilks, C.; Noakes, E.; Clare, G.; Barrington, A.; Brash, D.; et al. Efficacy of quarantine treatments using reduced methyl bromide concentrations to disinfest Pinus radiata logs from New Zealand. J. Stored Prod. Res. 2020, 89, 101718. [CrossRef]

10. Stejskal, V.; Douda, O.; Zouhar, M.; Manasova, M.; Dlouhy, M.; Simbera, J.; Aulicky, R. Wood penetration ability of hydrogen cyanide and its efficacy for fumigation of Anoplophora glabripennis, Hylotrupes bajulus (Coleoptera), and Bursaphelenchus xylophilus (Nematoda). Int. Biodeterior. Biodegrad. 2014, 86, 189-195. [CrossRef]

11. Douda, O.; Manasova, M.; Zouhar, M.; Hnatek, J.; Stejskal, V. Field validation of the effect of soil fumigation of ethanedinitrile (EDN) on the Mortality of Meloidogyne hapla and Carrot Yield Parameters. Agronomy 2021, 11, 208. [CrossRef]

12. Centers for Disease Control and Prevention. Available online: https://www.cdc.gov/niosh/npg/npgd0161.html (accessed on 2 November 2021).

13. Hall, M.; Najar-Rodriguez, A.; Pranamornkith, T.; Adlam, A.; Hall, A.; Brash, D. Influence of dose, bark cover and end-grain sealing on ethanedinitrile $\left(\mathrm{C}_{2} \mathrm{~N}_{2}\right)$ sorption by pine (Pinus radiata D. Don) logs. N. Z. Plant Prot. 2015, 68, 13-18. [CrossRef]

14. Hall, M.; Najar-Rodriguez, A.; Adlam, A.; Hall, A.; Brash, D. Sorption and desorption characteristics of methyl bromide during and after fumigation of pine (Pinus radiata D. Don) logs. Pest Manag. Sci. 2017, 73, 874-879. [CrossRef]

15. Ren, Y.L.; Lee, B.H.; Padovan, B. Penetration of methyl bromide, sulfuryl fluoride, ethanedinitrile and phosphine into timber blocks and the sorption rate of the fumigants. J. Stored Prod. Res. 2011, 47, 63-68. [CrossRef]

16. Najar-Rodriguez, A.J.; Afsar, S.; Esfandi, K.; Hall, M.; Adlam, A.; Wilks, C.; Noakes, E.; Richards, K. Laboratory toxicity and large-scale commercial validation of the efficacy of ethanedinitrile, a potential alternative fumigant to methyl bromide, to disinfest New Zealand Pinus radiata export logs. J. Stored Prod. Res. 2020, 88, 101671. [CrossRef]

17. Pranamornkith, T.; Hall, M.K.D.; Najar-Rodriguez, A.; Adlam, A.R.; Somerfield, K.G.; Page, B.B.C.; Hedderley, D.I.; Brash, D.W. Ethanedinitrile potential methyl bromide alternative to control Arhopalus ferus (Mulsant) in New Zealand sawn timber exports. N. Z. Plant Prot. 2014, 67, 75-79. [CrossRef] 
18. Najar-Rodriguez, A.J.; Hall, M.K.D.; Adlam, A.R.; Hall, A.J.; Burgess, S.B.; Somerfield, K.G.; Page, B.B.C.; Brash, D.W. Developing new fumigation schedules for the phytosanitary treatment of New Zealand export logs comparative toxicity of two fumigants to the burnt pine longhorn beetle Arhopalus ferus. N. Z. Plant Prot. 2015, 68, 19-25. [CrossRef]

19. Douda, O.; Stejskal, V.; Manasova, M.; Zouhar, M.; Hnatek, J. Inexpensive screening method to validate the efficacy of ethanedinitrile fumigant on the forest invasive nematode pest Bursaphelenchus xylophilus. Sustainability 2020, 12, 4765. [CrossRef]

20. Park, M.-G.; Ren, Y.; Lee, B.-H. Preliminary study to evaluate ethanedinitrile $\left(\mathrm{C}_{2} \mathrm{~N}_{2}\right)$ for quarantine treatment of four wood destroying pests. Pest Manag. Sci. 2021, 77, 5213-5219. [CrossRef]

21. Hnatek, J.; Stejskal, V.; Jonas, A.; Malkova, J.; Aulicky, R.; Weiss, V. Two new fumigation preparations (EDN ${ }^{\circledR}$ and BLUEFUMETM) to control soil, wood, timber, structural and stored product pest arthropods-An overview. Kharkov Entomol. Soc. Gaz. 2018, 26, 115-118.

22. Ramadan, G.R.M.; Abdelgaleil, S.A.M.; Shawir, M.S.; El-bakary, A.S.; Edde, P.A.; Phillips, T.W. Sorption of ethanedinitrile in fumigated commodities and its impact on efficacy for Rhyzopertha dominica (Coleoptera: Bostrichidae) and Lasioderma serricorne, (Coleoptera: Anobiidae) control. J. Stored Prod. Res. 2020, 86. [CrossRef]

23. Ren, Y.L.; Sarwar, M.; Wright, E.J. Development of cyanogen for soil fumigation. In Proceedings of the 2002 Annual International Research Conference on Methyl Bromide Alternatives and Emissions Reductions, Orlando, FL, USA, 6-8 November 2002; Presentation 63. pp. 1-4.

24. Hall, M.; Adlam, A.; Matich, A.; Najar-Rodriguez, A.; Pal, P.; Brash, D. Quantification of hydrogen cyanide as a potential decomposition product of ethanedinitrile during pine log fumigation. N. Z. J. For. Sci. 2018, 48, 7. [CrossRef]

25. Park, C.G.; Son, J.; Lee, B.; Cho, J.H.; Ren, Y.L. Comparison of ethanedinitrile $\left(\mathrm{C}_{2} \mathrm{~N}_{2}\right)$ and metam sodium for control of Bursaphelenchus xylophilus (Nematoda: Aphelenchidae) and Monochanus alternatus (Coleoptera: Cerambycidae) in naturally infested logs at low temperatures. J. Econ. Entomol. 2014, 107, 2055-2060. [CrossRef] [PubMed]

26. Park, C.-G.; Cho, J.-H.; Yoo, M.; Kim, B.-S.; Lee, B.-H.; Ren, Y. Ethandinitirile $\left(\mathrm{C}_{2} \mathrm{~N}_{2}\right)$ : Timber and log fumigation update. In Proceedings of the 9th International Conference on Controlled Atmosphere and Fumigation in Stored Products, Antalya, Turkey, 15-19 October 2012; Navarro, S., Banks, H.J., Jayas, D.S., Bell, C.H., Noyes, R.T., Ferizli, A.G., Emekci, M., Isikber, A.A., Alagusundaram, K., Eds.; ARB ER Professional Congress Services: Ankara, Turkey; pp. 421-425.

27. Lee, B.-H.; Yang, J.-O.; Beckett, S.; Ren, Y. Preliminary trials of ethanedinitrile $\left(\mathrm{C}_{2} \mathrm{~N}_{2}\right)$ fumigation of logs for eradication of Bursaphelenchus xylophilus and its vector insect Monochamus alternatus. Pest Manag. Sci. 2017, 73, 1446-1452. [CrossRef] [PubMed]

28. Thoms, E.M.; Busacca, J.D. Fumigants. In Encyclopedia of Food and Health; Caballero, B., Finglas, P.M., Toldrá, F., Eds.; Academic Press: Cambridge, MA, USA, 2015; pp. 150-156.

29. Bond, E.J. Manual of Fumigation for Insect Control; FAO Plant Production and Protection Paper No. 54; FAO: Rome, Italy, 1984.

30. Monro, H.A.U. Manual of Fumigation for Insect Control, 2nd. ed.; FAO: Rome, Italy, 1969; p. 381.

31. Agrafioti, P.; Sotiroudas, V.; Kaloudis, E.; Bantas, S.; Athanassiou, C.G. Real time monitoring of phosphine and insect mortality in different storage facilities. J. Stored Prod. Res. 2020, 89. [CrossRef]

32. Wu, F.; Qushim, B.; Guan, Z.; Boyd, N.S.; Vallad, G.E.; MacRae, A.; Jacoby, T. Weather Uncertainty and Efficacy of Fumigation in Tomato Production. Sustainability 2020, 12, 199. [CrossRef]

33. Rajendran, S. Fumigation of Shipping or freight containers. Outlooks Pest Manag. 2004, 15, 222-228. [CrossRef]

34. Stejskal, V.; Vendl, T.; Kolar, V.; LI, Z.; Aulicky, R. First population quantification of the infestation of legumes by stored-product bruchids imported in freight containers into Europe. Bull. Insectology 2020, 73, 233-239.

35. Someren Graver, J.E. Guide to Fumigation under Gas Proof Sheets, FAO 2004. Available online: https://www.fao.org/3/a-AU0 98e.pdf (accessed on 6 August 2021).

36. Rajendran, S.; Muralidharan, N.; Muralidharan, N. Phosphine retention in new and aged fumigation sheets. J. Sci. Ind. Res. 2003, 62, 184-187.

37. Aulicky, R.; Stejskal, V.; Frydova, B. Field validation of phosphine efficacy on the first recorded resistant strains of Sitophilus granarius and Tribolium castaneum from the Czech Republic. J. Stored Prod. Res. 2019, 81, 107-113. [CrossRef]

38. Stejskal, V.; Vendl, T.; Li, Z.; Aulicky, R. Minimal thermal requirements for development and activity of stored product and food industry pests (Acari, Coleoptera, Lepidoptera, Psocoptera, Diptera and Blattodea): A Review. Insects 2019, 10, 149. [CrossRef]

39. Maier, D.; Bhadriraju, S.; Chayaprasert, W. Comparison of leakage rates of methyl bromide and sulfuryl fluoride during structural fumigations. In Proceedings of the 10th International Working Conference on Stored Product Protection, Estoril, Portugal, 27 June-2 July 2010; Julius Kühn-Institut: Berlin, Germany, 2010.

40. Plumier, B.M.; Maier, D.E. Sensitivity analysis of a fumigant movement and loss model for bulk stored grain to predict effects of environmental conditions and operational variables on fumigation efficacy. J. Stored Prod. Res. 2018, 78, 18-26. [CrossRef]

41. Stejskal, V.; Jonáš, A.; Hnátek, J.; Aulicky, R.; Mochán, M.; Vybíral, O. Nová technologie fumigace dřeva proti kůrovcům. Lesn. Práce 2017, 96, 19-21. (In Czech)

42. Aulicky, R.; Stejskal, V.; Vendl, T.; Vybíral, O.; Mochán, M.; Hnátek, J.; Jonáš, A. Fumigace dřeva pomocí přípravku EDN. Lesn. Práce 2018, 97, 43-45. (In Czech) 